\title{
MOTIF, DAMPAK PSIKOLOGIS, DAN DUKUNGAN PADA KORBAN PERDAGANGAN MANUSIA DI NUSA TENGGARA TIMUR
}

\author{
Indra Yohanes Kiling ${ }^{\mathbf{1}} \&$ Beatriks Novianti Kiling-Bunga ${ }^{2}$ \\ Universitas Nusa Cendana, Jl. Adi Sucipto Penfui No.85001, Lasiana, Klp. Lima, Kota Kupang, Nusa Tenggara \\ Timur, Indonesia
}

Korespondensi:

le-mail: iykiling@gmail.com; ${ }^{2}$-mail: boenga.eve@gmail.com

\begin{abstract}
Female adults in East Nusa Tenggara (Nusa Tenggara Timur; NTT) are at risk to be victims of national and international human trafficking. This research describes the motives, psychological impacts, and supports perceived by adult female victims from NTT. Qualitative approach was applied with thematic analysis as the analysis method. Participants were five victims of human trafficking aged between 21 - 37 years old who have returned to NTT. It was found that participants were motivated to worked outside NTT due to economical, familial, and social reasons, while some other participants also reported being forced to work abroad. The perceived psychological impacts were maladaptive behaviors, deep sadness, helplessness, and being ashamed by stigma associated with being victims. Supports that were positively meaningful were the opportunity to share with other victims and to have a counseling sessions with mental health practitioners. Initiative to improve mental health services is indispensable as a base to combat human trafficking and to support victims.
\end{abstract}

Article history:

Received 9 Oktober 2018

Received in revised form 4 November 2018

Accepted 27 November 2018

Available online 1 March 2019

\section{Keywords:}

human trafficking;

motive;

psychological impact;

support

\begin{abstract}
Abstrak - Wanita dewasa di Nusa Tenggara Timur (NTT) rentan terhadap kejahatan perdagangan manusia, baik dalam skala nasional maupun internasional. Penelitian ini mendeskripsikan tentang motif, dampak psikologis, dan dukungan yang dipersepsi oleh wanita dewasa dari NTT yang berhasil bertahan hidup dari pengalaman menjadi korban perdagangan manusia. Pendekatan kualitatif diaplikasikan dalam penelitian ini, dengan analisis tematik sebagai teknik analisis. Partisipan adalah lima orang wanita berusia antara 21-37 tahun yang dijadikan pekerja ilegal di luar NTT dan telah kembali ke NTT. Ditemukan bahwa motif yang mendorong partisipan untuk bekerja di luar NTT adalah motif ekonomi, keluarga, sosial, dan paksaan. Dampak psikologis yang dialami adalah perilaku maladaptif, rasa sedih yang mendalam dan tak berdaya, serta rasa malu oleh stigma. Dukungan yang dimaknai secara positif adalah kesempatan untuk berbagi semangat dengan sesama korban dan sesi konseling dengan praktisi kesehatan mental. Inisiatif untuk meningkatkan pelayanan kesehatan mental sangat dibutuhkan sebagai dasar untuk melawan perdagangan manusia dan untuk mendukung korban.
\end{abstract}

Kata Kunci: perdagangan manusia; motif; dampak psikologis; dukungan 


\section{PENDAHULUAN}

Perdagangan manusia bukanlah masalah baru, termasuk di Asia Tenggara dan salah satunya di Indonesia. Perbudakan era modern ini telah mendapat julukan sebagai 'aib internasional' (international shame). Sebagai topik yang penting di mata dunia internasional, perdagangan manusia menarik perhatian berbagai macam kalangan, mulai dari pemerintah, lembaga nonpemerintah, sampai kepada selebriti yang sering bertindak sebagai penyelamat korban (Haynes, 2014). Masalah ini begitu lama menggerogoti peradaban manusia, namun juga belum berhasil ditangani dengan baik (Rafferty, 2007).

Definisi perdagangan manusia dibangun secara berbeda oleh beberapa organisasi internasional, seperti Perserikatan Bangsa-Bangsa (PBB), International Organization of Migration (IOM), dan International Labor Organization (ILO). Definisi dari PBB menyatakan bahwa elemen utama dalam perdagangan manusia ialah penggunaan ancaman, penipuan, dan pemaksaan (United Nations Office On Drugs and Crime [UNODC], 2019). Pemerintah Indonesia mendefinisikan perdagangan manusia dalam Undang-Undang Nomor 21 Tahun 2007 Pasal 1 sebagai tindakan perekrutan, pengangkutan, penampungan, pengiriman, pemindahan, atau penerimaan seseorang dengan ancaman kekerasan, penggunaan kekerasan, penculikan, penyekapan, pemalsuan, penipuan, penyalahgunaan kekuasaan atau posisi rentan, penjeratan utang atau memberi bayaran atau manfaat, sehingga memeroleh persetujuan dari orang yang memegang kendali atas orang lain tersebut, baik yang dilakukan di dalam negara maupun antar negara untuk tujuan eksploitasi atau mengakibatkan orang tereksploitasi (Undang-Undang Republik Indonesia, 2007).

Perdagangan manusia beroperasi dengan subur di daerah yang membutuhkan banyak pekerjaan (Petrunov, 2014) dan yang marak dengan praktik prostitusi (Cho, Dreher, \& Neumayer, 2013). Area negara-negara berkembang seperti ASEAN membutuhkan banyak pekerjaan sehingga rawan akan perdagangan manusia (Ismail, 2018). Sebagai negara yang memiliki banyak penduduk, tentunya Indonesia membutuhkan jumlah pekerjaan yang banyak pula. Terkait hal tersebut, ancaman, penipuan, dan pemaksaan dalam rangka mempekerjakan manusia telah berulang kali terjadi di Indonesia. IOM mencatat Indonesia merupakan negara urutan ke-13 dengan kasus perdagangan terbanyak yang ditangani oleh organisasi ini (International Organization of Migration [IOM], 2012). Di Nusa Tenggara Timur (NTT), perdagangan manusia masih menjadi salah satu permasalahan utama yang menjadi perhatian pemerintah daerah NTT, bahkan pemerintah pusat ('Jokowi: Stop perdagangan manusia", 2014). Data Kementerian Sosial menyatakan bahwa pada 
tahun 2014, NTT menduduki peringkat dua nasional dalam hal kasus perdagangan manusia (Institute Resource Governance and Social Change [IRGSC], 2014). Data yang dihimpun dari berbagai sumber menunjukkan jumlah korban perdagangan manusia di NTT pada tahun 2014 mencapai 1,021 korban, beberapa kasus bahkan telah menelan korban nyawa (IRGSC, 2014).

Maraknya perdagangan manusia yang terjadi di NTT membutuhkan campur tangan para ahli untuk memberikan dukungan, baik secara hukum, sosial, maupun psikologis kepada para korban yang telah kembali di NTT (survivor atau penyintas). Penyintas didefinisikan dalam Kamus Besar Bahasa Indonesia sebagai orang yang terus bertahan hidup (Kamus Besar Bahasa Indonesia, 2018). Wilfrida Soik, salah satu korban perdagangan manusia dari NTT yang terdiagnosa dengan gangguan kejiwaan akut dan gangguan psikotik sementara (acute and transient psychotic disorders) (IRGSC, 2014) merupakan salah satu contoh nyata korban perdagangan manusia yang membutuhkan campur tangan dari ahli kejiwaan. Sayangnya, peran psikolog sering kali tidak dianggap sebagai kebutuhan utama sehingga sering diminimalisir. Hal lain yang juga bisa memengaruhi minimalnya layanan psikologis adalah karena sistem dan sumber daya yang ada belum didesain sedemikian rupa untuk mendukung dan menolong para korban perdagangan manusia, sebagaimana yang terjadi di negara maju, seperti Amerika Serikat (Bergman, 2013; Clayton, Krugman, \& Simon, 2013).

Psikolog sebenarnya dapat memberi sumbangsih dalam mereduksi perilaku penyalahgunaan otoritas yang sering berujung pada perdagangan manusia, maupun dalam memberikan terapi untuk mengembalikan keadaan psikologis dari korban perdagangan manusia (Hom \& Woods, 2013). Hal ini menjadi lebih krusial mengingat korban perdagangan manusia adalah mayoritas perempuan dan anak-anak yang lebih rentan terkena dampak negatif pada kondisi mentalnya (Havlicek, Huston, Boughton, \& Zhang, 2016). Memahami perilaku, kognisi, emosi, serta dukungan sosial yang dialami oleh korban dapat membantu praktisi psikologi untuk memberikan bantuan psikologis secara tepat (Cunningham \& Cromer, 2016).

Trauma emosional dan fisik, rasa takut dan cemas yang tinggi, depresi, rendahnya percaya diri, serta tendensi bunuh diri merupakan beberapa masalah psikologis yang sering dialami oleh korban perdagangan manusia, terutama anak-anak dan wanita (Rafferty, 2007; UNODC, 2009). World Health Organization [WHO] (2012) kemudian secara eksplisit mengisyaratkan bahwa kajian akademis mengenai dampak psikologis pada korban pasca perdagangan manusia (post-trafficking) sangat dibutuhkan untuk memperluas sudut pandang ilmu kesehatan dalam kaitannya dengan perdagangan manusia. Rangkuman informasi yang dihimpun pada tahun 2014 memperlihatkan 
bahwa perhatian terhadap korban perdagangan manusia di NTT masih bertumpu pada penyelesaian masalah hukum, sedangkan masih sedikit informasi yang diberikan terkait intervensi psikologis pasca perdagangan manusia, sehingga perlu penelaahan lebih lanjut (IRGSC, 2014).

Penelitian ini bertujuan untuk memahami fungsi psikologis dan dukungan sosial yang dialami korban wanita pasca perdagangan manusia, serta mendeskripsikan, dan menganalisa fungsi praktik rehabilitasi dan program prevensi yang kontekstual dengan konteks daerah asal korban, yakni Kupang, NTT. Pertanyaan penelitian ini adalah: Bagaimana dampak pengalaman menjadi korban perdagangan manusia? Temuan penelitian ini diharapkan dapat memberikan masukan pada pemerhati perdagangan manusia di NTT, terutama dalam memberikan penanganan secara psikologis.

\section{METODE}

\section{Partisipan}

Partisipan terdiri dari lima orang. Partisipan 1, 3, dan 4 adalah korban perdagangan manusia yang masih anak-anak ketika menjadi korban, sementara partisipan lainnya adalah wanita dewasa yang menjadi korban perdagangan manusia. Deskripsi singkat data diri partisipan penelitian terlihat pada Tabel 1.

Tabel 1.

Data Diri Partisipan

\begin{tabular}{cclll}
\hline Inisial & \multicolumn{1}{c}{ Usia } & \multicolumn{1}{c}{ Asal } & Jenis Kelamin & \multicolumn{1}{c}{ Pendidikan Terakhir } \\
\hline Partisipan 1 (P1) & 22 tahun & Kab. Kupang & Perempuan & Tidak pernah sekolah \\
Partisipan 2 (P2) & 27 tahun & Kab. Kupang & Perempuan & Sekolah Dasar \\
Partisipan 3 (P3) & 32 tahun & Kab. Kupang & Perempuan & Sekolah Menengah Pertama \\
Partisipan 4 (P4) & 21 tahun & Kab.Flores Timur & Perempuan & Sekolah Dasar \\
Partisipan 5 (P5) & 37 tahun & Kab.Flores Timur & Perempuan & Sekolah Menengah Pertama \\
\hline
\end{tabular}

P1 masih tergolong remaja (usia 17 tahun) ketika bekerja ke Medan, Sumatera Utara, pada tahun 2011. Sejak lahir sampai berusia 17 tahun, P1 tinggal bersama orang tuanya di Kupang, NTT. P2 bekerja ke Medan bersamaan dengan P1 pada tahun 2011. P2 juga baru pertama kali keluar dari NTT saat beranjak pergi ke Medan. Kedua partisipan merupakan korban perdagangan manusia di Medan, yang merupakan bagian dari total 28 TKI ilegal yang diperlakukan tidak manusiawi di sebuah perusahaan sarang burung walet (IRGSC, 2014). P1 dan P2 juga mendapatkan perlakuanperlakuan negatif di perusahaan tempat mereka bekerja, seperti sering dibentak dan dihina, tidak 
boleh menelepon keluarga, hanya diberikan waktu istirahat satu kali dalam tiga minggu, tidak boleh bercerita dengan sesama pekerja, dan secara rutin diberikan makanan yang kurang layak, seperti bubur dengan bawang. Kedua partisipan telah kembali ke NTT pada bulan April 2014 dan menjalani kehidupan pasca pengalaman diperdagangkan.

Usia P3 saat berangkat juga masih berusia 17 tahun. Ia memutuskan untuk bekerja ke Malaysia karena ditawari oleh seseorang yang ia kenal di pasar, yang kemudian dikenalkan kepada penyalur tenaga kerja legal pada tahun 2001, lalu bekerja di sana selama 2 tahun. Tahun 2007 P3 kembali tergiur untuk bekerja di Malaysia karena alasan ekonomi tidak membaik setelah menikah. Di sana P3 dijanjikan akan bekerja sebagai pelayan toko, tetapi ternyata mereka dijual dan dijadikan Pekerja Seks Komersial (PSK). Kini ia bekerja sebagai penjaga toko di Kupang.

P4 menjadi korban perdagangan di Malaysia yang berhasil kabur. Awalnya ia bersama beberapa temannya dari kampung ditawari bekerja di luar negeri oleh seorang agen yang memang datang untuk mencari orang yang mau bekerja di luar negeri. Saat itu ia berumur 16 tahun. Setelah kembali ke Indonesia, P4 pulang ke kampungnya dan sekarang bekerja di Kupang sebagai penjaga toko.

P5 sejak lulus SMP sudah bekerja membantu keluarga menjual kue. Setelah itu, P5 bekerja di Singapura. P5 dikenalkan saudaranya kepada seorang penghubung untuk mengurus segala persyaratan keberangkatannya. Sebelumnya, P5 dijanjikan untuk bekerja di sebuah pabrik, tetapi akhirnya dijadikan PSK. Tiga bulan setelah bekerja sebagai PSK, P5 berhasil kabur bersama beberapa temannya. Mereka berhasil kembali ke Indonesia dan sekarang P5 tinggal bersama temannya, serta bekerja sebagai penjaga warung di Kupang.

\section{Desain}

Penelitian ini merupakan penelitian kualitatif. Penelitian kualitatif merupakan pendekatan yang penting untuk memahami suatu fenomena sosial dan perspektif individu yang diteliti. Partisipan direkrut melalui pengambilan sampel secara sengaja (purposive sampling), di mana partisipan dipilih berdasarkan tujuan penelitian (Welman \& Kruger, 1999). Karakteristik partisipan adalah wanita dewasa (berusia lebih besar dari 18 tahun) yang merupakan korban perdagangan manusia yang berasal dari NTT dan telah kembali menetap di NTT selama minimal satu bulan. Pencarian partisipan dilakukan dengan bantuan dari organisasi aktivis perdagangan manusia yang mengetahui lokasi kerja para korban perdagangan manusia di NTT saat ini. Lokasi penelitian yang terpilih adalah di Kupang, NTT. 
Partisipan yang bersedia untuk mengikuti penelitian diikutkan dalam penelitian. Peneliti berusaha menjaga kondisi psikologis partisipan dengan mempersilakan partisipan untuk menarik partisipasinya dari wawancara atau keseluruhan rangkaian penelitian kapan pun diinginkan. Peneliti juga menyediakan akses kepada bantuan psikologis, seperti bantuan psikolog, jika ada dampak negatif yang dirasakan partisipan selama proses penelitian.

\section{Prosedur}

Wawancara dan observasi dipilih sebagai metode pengumpulan data. Wawancara tidak terstruktur dilakukan dengan pertanyaan penelitian yang diajukan meliputi: 'Apa yang Anda alami dalam proses perdagangan orang?' dan 'Apa dampak yang Anda rasakan dari proses yang telah terjadi?' Pertanyaan-pertanyaan diarahkan kepada pengalaman, perasaan, keyakinan, dan pendapat terkait tema penelitian (Welman \& Kruger, 1999). Peneliti memilih untuk fokus kepada apa yang terjadi di dalam diri partisipan dan meminta partisipan untuk mendeksripsikan pengalaman yang dialami dalam bahasa yang sebebas mungkin dari konstruk umum dan intelek (Bentz \& Shapiro, 1998).

Wawancara dan observasi dilakukan di tempat kerja partisipan. Selain itu, pengumpulan data dilakukan juga dengan menggunakan telepon genggam. Wawancara dengan P1 dan P2 dilakukan sebanyak dua kali dengan total durasi wawancara berturut-turut 103 menit dan 118 menit. Wawancara dengan P3, P4, dan P5 dilakukan masing-masing sebanyak satu kali dengan total durasi wawancara berturut-turut 51 menit, 45 menit, dan 42 menit.

Untuk memenuhi aspek etika, persetujuan verbal diperoleh dari semua partisipan. Wawancara dilakukan dengan memerhatikan 10 prinsip etis dalam melakukan wawancara kepada wanita korban perdagangan manusia dari WHO, yakni: (1) jangan mengambil risiko yang bisa membahayakan partisipan, (2) kenali partisipan, (3) siapkan informasi/informan cadangan, (4) pilih rekan peneliti yang kapabel, (5) pastikan kerahasiaan identitas, (6) dapatkan ijin dari partisipan, (7) dengar dan hargai penilaian partisipan terhadap keselamatan mereka, (8) jangan mengembalikan trauma korban, (9) bersiap untuk keadaan darurat, dan (10) gunakan informasi yang didapat sebaik mungkin (Zimmerman \& Watts, 2004).

Triangulasi data dilakukan dengan teknik triangulasi dari sumber yang berbeda, yakni data sekunder yang diperoleh dari media massa dan literatur (IRGSC, 2014) dan data catatan observasi (observational notes) dari masing-masing partisipan penelitian. Triangulasi dari peneliti yang 
berbeda juga dilakukan, yaitu dua orang peneliti terlibat aktif dalam proses analisa data untuk mengecek validitas data (Denzin \& Lincoln, 1994).

\section{Teknik Analisis}

Analisa data dilakukan dengan pendekatan analisis tematik (Clarke \& Braun, 2013). Proses analisa dimulai dengan familiarisasi data, yakni membaca transkrip wawancara. Kemudian, proses pemberian kode dilakukan oleh penulis pertama pada tiga transkrip dan penulis kedua pada dua transkrip lainnya. Kedua penulis kemudian bertemu untuk mendiskusikan kode tersebut lalu mengembangkan tema-tema. Tema kemudian ditinjau kembali bersama dengan cara melihat relevansi dengan data (membaca kembali transkrip), lalu tema diberi nama. Proses terakhir adalah memilih kutipan partisipan yang tepat untuk merepresentasikan tema-tema.

\section{ANALISIS DAN HASIL}

Berdasarkan hasil wawancara dan observasi terhadap partisipan, maka diperoleh beberapa tema sebagai berikut.

\section{Motif Bekerja di Luar NTT}

Kentalnya rasa kekeluargaan dan kerasnya kehidupan di NTT yang ditandai dengan kondisi geografis yang kurang mendukung, lapangan pekerjaan yang terbatas, akses pendidikan yang kurang, dan infrastruktur yang kurang memadai memicu timbulnya kemiskinan dan pengangguran di desa. Hal ini mendorong orang muda di desa hijrah ke kota untuk mencari kehidupan yang menurut mereka lebih baik dan mampu membuat mereka menjalankan peran untuk membantu orang tua. Beberapa alasan mengapa partisipan memutuskan untuk bekerja di luar NTT adalah alasan ekonomi, keluarga, sosial, dan karena paksaan.

Ekonomi. Ketika ditanya mengenai alasan memutuskan bekerja di luar negeri, jawaban yang pertama diucapkan P1 adalah: "Beta (saya) pengen cari uang, supaya buat bantu nenek.” P2 juga mengaku bahwa alasan utama ia pergi bekerja di Medan adalah uang. P2 tertarik dengan gaji yang besar serta kontrak dua tahun yang dirasanya cukup menjamin kehidupan. Alasan ini memperlihatkan bahwa bekerja di luar NTT dipersepsikan partisipan sebagai langkah mudah untuk memperoleh jumlah uang yang dianggap besar, seperti yang diungkapkan P4: 
"Yang penting kami dapat kerjaan. Apalagi syarat-syaratnya mudah dan kami tinggal berangkat, tidak perlu repot baurus sana-sini... mau gaji besar ya harus ke luar negeri. Ada orang yang tawar dengan syarat gampang, kami bersedia saja."

Terlihat di sini bahwa kondisi ekonomi yang mendesak dapat membuat para individu menutup mata terhadap berita tentang hal-hal buruk yang menimpa orang yang menjadi korban perdagangan. Sebagaimana pada isu sosial lain, seperti disabilitas dan praktik prostitusi, keadaan ekonomi merupakan faktor risiko penting yang menyebabkan seseorang terjebak dalam praktik perdagangan manusia, sulit untuk keluar sehingga menjadi korban berulang kali karena alasan keuangan tersebut.

Keluarga. Alasan keluarga berkaitan dengan membantu serta menyenangkan keluarga. Masyarakat asli NTT, sebagaimana layaknya di daerah lain di Indonesia, memiliki kerekatan yang baik dengan anggota keluarga sehingga membantu anggota keluarga, terutama yang tinggal serumah, menjadi salah satu motivasi partisipan. Empat partisipan sama-sama memiliki alasan ini. Kebiasaan ini secara turun-temurun diwariskan sebagai perilaku yang umum di keluarga mereka, sehingga membantu internalisasi perilaku tersebut pada berbagai generasi. P5 mengungkapkan pernyataan yang berkaitan dengan hal tersebut:

"Di keluarga kami, kalau sudah besar harus keluar merantau mencari uang untuk membantu orang tua, nah bagaimana kan, siapa lagi yang bisa bantu kita punya orang tua selain kita sendiri. Masa kita mau kasi biar orangtua yang sudah kasi besar kita, biar lei (lagi) mereka tidak mampu kasih sekolah kita tinggi-tinggi, tetap kita harus berusaha bantu mereka."

Dalam kasus P5, anggota keluarga justru secara tidak langsung menjadi salah satu aktor yang memungkinkan P5 dieksploitasi dalam perdagangan orang. Hal ini mengindikasikan bahwa peran keluarga sangat krusial dalam menyambung dan memutus mata rantai perdagangan orang. Oleh karena itu, penanganan komunitas yang berkonsentrasi terhadap pendekatan keluarga menjadi langkah strategis untuk dilakukan.

Sosial. Termasuk dalam alasan ini ialah motivasi untuk meniru kesuksesan tetangga atau saudara yang pulang merantau, serta ingin melihat bagian lain dari dunia selain NTT untuk meningkatkan derajat sosial. Semua partisipan tinggal di daerah yang mana mayoritas perempuan bekerja sebagai tenaga kerja domestik, baik di dalam maupun luar negeri. Partisipan melihat bekerja di luar NTT berhasil mendatangkan keuntungan material yang baik, sehingga mereka menjadi tertarik untuk menirunya. Dapat dilihat perilaku meniru ini berhubungan erat dengan faktor ekonomi. P2 mengaku ingin melihat Medan yang dirasa pasti berbeda dengan Kupang, sedangkan 
P3, P4, dan P5 merasa bahwa pengalaman menginjak luar negara Indonesia akan mengangkat derajat sosial mereka di mata masyarakat, sebagaimana disampaikan P3:

"Waktu itu biar keren toh, kan sonde (tidak) semua yang bisa pi (pergi) di luar negeri. Katong (kita) bisa lihat orang luar dong (mereka) punya cara hidup yang rapi, nda sama kek di sini ni. Katong (kita) ju bisa pake ini baju-baju luar negeri dong, makan makanan yang beda-beda ju (juga), baru pas pulang kas (kasih) cerita sama sudara dong semua biar dong juga semangat."

Era digital yang memungkinkan foto dan video untuk mengangkat derajat seseorang dalam lingkaran sosialnya menjadi jembatan yang mengantar individu di NTT untuk bekerja ke luar daerah, meski tanpa kejelasan legalitas.

Paksaan. P1 sempat mendapat tekanan dari perekrutnya, yakni Ibu R. Ibu R mengatakan bahwa dia sudah membelikan tiket pesawat terbang untuk P1, sehingga jika P1 membatalkan maka P1 harus mengganti uang tiket tersebut. P5 juga tidak bisa berbuat apa-apa walaupun sudah merasa ada yang janggal ketika masih berada di tempat penampungan tenaga kerja. Faktor eksternal ini menjadi perangkap bagi partisipan yang membuat mereka tidak dapat membatalkan untuk bekerja di luar NTT. Keengganan menunjukkan asertivitas pada mayoritas masyarakat Indonesia juga mempermudah terjadinya proses pemaksaaan pada perdagangan orang.

\section{Dampak Psikologis Terhadap Korban Perdagangan Orang}

Setelah kembali bekerja di lingkungan yang familiar, partisipan masih merasakan beberapa dampak dari perdagangan manusia. Dampak pengalaman diperdagangkan terhadap para partisipan adalah: kecenderungan berperilaku selalu patuh, merasa sedih yang berkepanjangan, dan rasa malu yang mendalam.

Perilaku untuk selalu patuh (ibarat robot pekerja). Partisipan memaknai hidup mereka untuk terus bekerja. Perilaku ini terus terbawa, bahkan setelah mereka bekerja di Kupang. Makna ini timbul dan tertanam kuat pada diri partisipan karena perilaku bekerja yang dilakukan terusmenerus pada saat bekerja di luar NTT. P1 menyinggung:

“Apa yang dong (mereka) minta pasti katong (kita) kerja itu. Ya yang katong (kita) tahu ya cuma ikut sa (saja) dengan apa yang disuruh toh. Katong (kita) kerjakan permintaan sampai selesai baru lihat apa lagi yang bisa dikerjakan." 
Pekerja yang selalu menurut dipengaruhi oleh kepercayaan dirinya yang kemudian dimanipulasi oleh banyak faktor, seperti: status sosial, pendidikan, dan lain-lain. Daerah-daerah yang banyak dihuni oleh masyarakat berpenghasilan rendah, tinggal di pedalaman, dan memiliki pendidikan yang rendah menjadi lumbung bagi para aktor perdagangan manusia yang memburu mangsanya.

Merasa sedih yang berkepanjangan. Ini terutama dialami karena kehilangan teman yang meninggal ketika masih di luar NTT. Rasa sedih ini disebabkan oleh rasa tidak berdaya dan tidak mampu untuk mencegah kematian temannya tersebut. Sedih dan rasa lemas yang terus-menerus juga dirasakan P3 dan P5 yang menjadi PSK di luar negeri. Rasa sedih ini terkait dengan rasa sakit dan malu pada diri sendiri karena harga diri sudah tidak ada dan juga karena telah menurunkan harga diri keluarga, seperti yang dikatakan P5:

"Saya hanya menangis terus saja. Rasa sedih sekali begitu sampai sekarang juga. Sakit sekali ini hati. Rasa-rasa kalau bisa mau putar kembali ini waktu supaya jang (jangan) jadi begitu. Tapi mau karmana (bagaimana) lagi, ya tahan-tahan saja ini rasa (sedih)."

Rasa sedih yang berkepanjangan ini menunjukkan gejala depresi pada partisipan, meskipun ini tidak dikonfirmasi oleh partisipan karena pemahaman yang terbatas terkait depresi. Kemampuan mengenali serta mengelola emosi yang rendah akan mempermudah partisipan untuk mengalami dampak negatif psikologis yang berkepanjangan.

Rasa malu yang sangat dalam juga disebabkan karena tidak membawa banyak uang bagi partisipan yang tidak terlibat dalam kegiatan prostitusi. Membawa uang banyak dianggap sebagai indikator kesuksesan dalam merantau, sehingga ketika tidak berhasil membawa uang yang banyak dianggap sebagai sebuah kegagalan. Sementara itu, rasa malu yang mendalam dimaknai oleh partisipan yang dijadikan PSK karena masalah harga diri dan juga pandangan masyarakat yang sangat negatif pada status 'eks-PSK'. Terlihat bahwa rasa malu terkait dengan stigma, baik stigma sebagai PSK maupun stigma sebagai perantau yang 'gagal' dalam membawa banyak uang. Pergi sebagai individu yang membawa nama baik di masyarakat karena berstatus sebagai 'orang kota', 'orang luar negeri', atau 'orang sukses' membuat proses kembali ke masyarakat sebagai korban perdagangan orang menjadi sebuah proses yang berat dan membutuhkan dukungan dari profesional.

\section{Dukungan yang Dipersepsi}

P1 dan P2 telah mendapatkan dukungan dari berbagai pihak. Ketika kabur dari perusahaan, P1 dan P2 sempat diungsikan ke sebuah rumah aman di Medan kemudian singgah satu bulan di 
Jakarta sebelum akhirnya dipulangkan ke NTT. Ketika berada dalam rumah aman di Medan dan Jakarta, P1 dan P2 sempat mendapatkan dukungan dari beberapa aktivis dari organisasi sosial (partisipan lupa dengan nama organisasi tersebut). P3, P4, dan P5 juga memperoleh dukungan dari Amanat Penderitaan Rakyat (AMPERA) NTT beserta dinas sosial provinsi NTT sesampainya mereka di Kupang. Dukungan yang mereka dapatkan tersebut berupa sesi sharing dengan temanteman aktivis, sesi konseling, kegiatan-kegiatan menyenangkan dengan permainan di dalam maupun luar ruangan. P1 dan P2 menyatakan bahwa dukungan yang paling membantu menenangkan mereka adalah ketika mendapatkan kata-kata positif dan memberi semangat dari sesama korban perdagangan manusia. Setelah mendapatkan pekerjaan kembali di Kupang, P1 dan P2 tidak pernah mendapatkan penanganan psikologis yang intensif. Hal ini memperlihatkan kecenderungan bahwa proses kembali ke masyarakat sudah tercapai ketika korban sudah mendapatkan kembali pekerjaan di daerah NTT, sehingga aktivitas terkait pemulihan dianggap tidak diperlukan lagi. P3 dan P5 memperoleh dukungan konseling dari aktivis sosial. Konseling tersebut dianggap membantu dalam mengungkapkan beban emosional yang dirasakan partisipan, seperti yang diutarakan oleh P3:

"Terus sempat juga beta dengan kawan-kawan dong ba (yang lain) konseling begitu dengan ada kakak satu, bilang dia ahli konseling begitu. Ya beta rasa baik juga, karena katong (kita) bisa cerita-cerita, sonde (tidak) takut-takut begitu. Sangat membantu katong (kita) buat kasih keluar emosi juga."

Peran keluarga sebagai penyedia dukungan sosial sendiri kurang dibahas oleh para partisipan, meskipun keluarga sebenarnya memiliki tugas yang penting dalam menyediakan dukungan yang dimaksud. Penjembatanan antara korban dan keluarga korban, serta anggota masyarakat lain perlu didorong oleh pihak yang memiliki sumber daya, seperti pemerintah dan lembaga non-pemerintah.

\section{DISKUSI}

Penelitian ini tidak difokuskan untuk menelusuri secara naratif proses perdagangan orang demi mengungkap jaringan pelaku, melainkan mencoba untuk mengetahui pemaknaan para korban terhadap pengalaman, serta dampak yang dialami ketika diperdagangkan, baik di dalam maupun luar Indonesia. Berdasarkan temuan penelitian, motif yang mendorong perempuan dari NTT untuk bekerja di luar NTT tergolong serupa dengan semua partisipan, yakni didorong oleh motif ekonomi, 
keluarga, sosial, serta paksaan. Seperti pada keadaan kelima partisipan, korban perdagangan manusia memang banyak yang berasal dari latar belakang sosio-ekonomi yang rendah, membutuhkan pekerjaan, serta merupakan pemudi yang sehat dan bugar. Kondisi mendesak untuk memperoleh penghasilan tetap (Petrunov, 2014) ditambah dengan rendahnya pendidikan yang ditempuh, seperti yang dialami kelima partisipan membuat korban lebih mudah ditipu dan dimanfaatkan (Stotts Jr \& Ramey, 2009). Kesulitan dari sisi ekonomi dan pendidikan kemudian ditambah dengan adanya dorongan untuk menjalankan peran ekonomi dalam keluarga, serta dorongan untuk meniru dan meningkatkan status sosial (social learning) membuat ketiga motif ini seringkali bekerja secara simultan untuk memperkuat dorongan bekerja sebagai tenaga kerja wanita (TKW) ilegal. Jika seorang TKW sampai berpikiran untuk mundur sebelum bekerja, maka motif paksaan pun muncul dari sisi agen atau penyalur tenaga kerja untuk memastikan TKW tidak berubah pikiran.

Motif-motif ini secara tidak langsung memperlihatkan beberapa faktor risiko lingkungan sosial terkait perdagangan manusia yang kontekstual dengan keadaan NTT, yakni kemiskinan, peran dalam keluarga, pandangan dalam komunitas, serta paksaan dari penyalur tenaga kerja. Beberapa faktor ini juga terlihat dalam rangkuman pemberitaan media massa di NTT mengenai perdagangan manusia pada tahun 2014 (IRGSC, 2014). Mempertimbangkan keempat faktor risiko ini dalam tindakan preventif ke komunitas diharapkan mampu mereduksi jumlah tenaga kerja Indonesia (TKI) ilegal yang adalah korban perdagangan manusia. Pemerintah daerah maupun aktivis dari Lembaga Swadaya Masyarakat (LSM) dan organisasi masyarakat (ormas) sendiri mulai menggalakkan program preventif, seperti sosialisasi maupun peningkatan kapasitas ekonomi masyarakat desa (IRGSC, 2014). Untuk meningkatkan efektivitas, keluarga perlu menjadi titik utama dari aktivitas preventif, sehingga keluarga mampu menjalankan peran sebagai faktor pelindung dari perdagangan manusia. Lingkungan dalam tingkat terkecil, seperti Rukun Tetangga dan Rukun Warga perlu diperkuat fungsinya sebagai radar yang mampu mendeteksi potensi perdagangan orang, seperti identitas palsu atau tidak memiliki identitas, belum memiliki pekerjaan, perekrut tenaga kerja ilegal, dan lain-lain. Undang-undang dan peraturan anti perdagangan manusia juga sangat dibutuhkan untuk memperkuat pertahanan terlebih dari sisi perekrut dan penyalur tenaga kerja, juga untuk menjamin bahwa penindakan memiliki landasan hukum yang kuat (Wooditch, 2012).

Selain penanganan yang bersifat preventif, intervensi psikologis tentu dibutuhkan untuk membantu korban dapat beradaptasi lagi dengan lingkungannya pasca pengalaman buruk yang 
dialami. Perilaku maladaptif robot pekerja, gejala depresi, serta rasa malu yang mendalam yang menjadi dampak utama yang dimaknai oleh partisipan penelitian ini perlu mendapatkan penanganan khusus dari sisi kejiwaan. Rasa malu (shame) yang dirasakan partisipan berulang kali disebutkan oleh dua partisipan. Rasa malu ini juga merupakan salah satu alasan yang membuat partisipan memilih untuk bekerja di Kupang, bukan di kampung halaman mereka. Rasa malu yang disebabkan oleh tidak memiliki uang dan rezeki ini berbeda dengan rasa malu yang dirasakan oleh korban perdagangan manusia yang dipekerjakan secara seksual. Pada korban yang dilecehkan atau dipekerjakan seksual secara paksa, rasa malu tersebut berkaitan dengan kehormatan dan harga diri kewanitaan yang dibangun dari konsep seksual (WHO, 2012). Dari sini dapat dilihat bahwa ada dua stigma berbeda yang mendorong rasa malu tersebut, yakni stigma sebagai perantau yang gagal dan stigma sebagai wanita yang tercoreng harga dirinya.

Rasa malu ini sering diikuti dengan rasa sedih serta tak berdaya yang mendorong mereka mengisolasi diri sendiri dari lingkungan sosialnya, yang akhirnya mempersulit proses pemulihan psikologis dari korban (Stotts Jr \& Ramey, 2009; WHO, 2012). Ketika dikombinasikan dengan kebiasaan perilaku maladaptif yang mengutamakan menghabiskan waktu dengan bekerja, maka korban bisa terperangkap dalam jebakan mental yang membuat korban susah merasakan kebahagiaan yang utuh dalam hidupnya (Hom \& Woods, 2013). Pembentukan perilaku seperti robot pekerja ini dikondisikan karena pengulangan aktivitas secara terus-menerus dan juga diperkuat oleh rasa tak berdaya dan terbatasnya akses terhadap tindakan penanganan kesehatan (Stotts Jr \& Ramey, 2009). Perilaku ini tentu akan membelenggu kebebasan berpikir dan bertindak korban, sehingga mental budak pun terbentuk. Keadaan mental sebagai budak ini identik dengan julukan perdagangan manusia sebagai perbudakan modern (modern slavery) (IRGSC, 2014).

Selanjutnya, perdagangan manusia juga memberi dampak sedih dan tak berdaya yang berkepanjangan yang merupakan gejala-gejala yang berkaitan erat dengan depresi. Gejala depresi ini dimaknai lebih kuat oleh korban perdagangan manusia yang dipaksa menjadi PSK. Hal ini memperkuat pernyataan bahwa depresi akan lebih mungkin muncul pada wanita yang mengalami kekerasan seksual yang tidak memperoleh penanganan kesehatan mental (Fuadi, 2011). Hal ini disebabkan oleh peristiwa traumatis yang dialami ketika seseorang mengalami kekerasan seksual, yang kemudian terus membekas di dalam memori korban. Serupa dengan perilaku maladaptif, rasa sedih dan tak berdaya ini berkaitan erat dengan faktor risiko minimalnya akses terhadap layanan kesehatan mental (Zimmerman \& Hossain, 2011), sehingga dapat disimpulkan bahwa stigma dan keterbatasan akses pada layanan kesehatan menjadi beberapa faktor risiko utama yang 
menyebabkan dampak perilaku maladaptif, rasa malu, dan rasa sedih pada partisipan dalam penelitian ini.

Korban yang diliputi dengan rasa malu, rasa sedih dan tak berdaya, serta perilaku maladaptif membutuhkan waktu yang lama untuk pulih. Oleh karena itu, penanganan jangka panjang dibutuhkan oleh para korban tersebut. Jika dikaitkan dengan temuan penelitian bahwa dukungan sosial yang bermakna dan berdampak positif adalah dari sesama korban dan dari konseling, maka proses pemulihan dari rasa malu dan tak berdaya bisa dilakukan dalam lingkup keluarga dan objek lekat (significant other) lainnya, seperti sesama korban perdagangan manusia. Terlepas dari berbagai penanganan, seperti sharing dengan aktivis dan melakukan kegiatan yang menyenangkan, korban memersepsikan bahwa kata semangat dan penghiburan dari teman sesama korban adalah kegiatan yang dirasa sangat berdampak untuk memulihkan keadaan mental mereka. Hal ini bisa dipahami karena wanita memiliki kecenderungan untuk berbagi dengan rekan sebaya mereka (Kleinschmidt, 2009). Rasa senasib sepenanggungan juga membantu korban untuk merasa bahwa mereka tidak sendirian dalam menghadapi kesulitan tersebut.

Praktisi psikologi maupun aktivis sosial lain perlu menginisiasi gerakan untuk menyediakan akses layanan kesehatan mental kepada korban perdagangan orang. Penelitian mengenai pelayanan kesehatan mental, seperti unit psikiatri di rumah sakit, masih sangat minimal jumlahnya (Nguyen, Coverdale, \& Gordon, 2017). Hasil penelitian Macy dan Johns (2011) menunjukkan bahwa dibutuhkan tindakan yang intensif dalam meningkatkan kesadaran dan kepekaan untuk bisa membuat para praktisi kesehatan maupun kesehatan mental mampu menyediakan layanan yang nyaman dan tepat sasaran dalam kasus-kasus perdagangan manusia. Studi tersebut menunjukkan pentingnya kesadaran dan inisiatif pemerintah, terutama dinas kesehatan dan LSM dalam mendorong praktisi kesehatan dan kesehatan mental di Indonesia, terkhusus di NTT, untuk lebih proaktif dalam memberikan penanganan dan menuliskan penemuan praktisnya. Penyediaan layanan kesehatan mental ini bisa berfungsi pula sebagai 'sekolah' untuk para korban dan anggota masyarakat belajar mengelola emosi, pemahaman konsep diri, berperilaku asertif, menempatkan diri dalam lingkup sosial dan digital, serta kemampuan psikologis lain yang dapat berfungsi sebagai pelindung dari praktik perdagangan manusia. Kerja sama intervensi dengan profesional lain, seperti pekerja sosial, juga dianjurkan untuk meningkatkan keberlangsungan dan efisiensi (Nguyen, Coverdale, \& Gordon, 2017). Tentu inisiatif seperti ini hanya dapat berfungsi jika data tentang perdagangan orang lebih mudah diakses dan tidak disembunyikan oleh para pemangku kepentingan, seperti yang terjadi selama ini (Konrad, Trapp, Palmbach, \& Blom, 2017). 
Bisa dilihat dari temuan penelitian bahwa korban perdagangan manusia mendapatkan perhatian secara hukum, namun kurang mendapatkan penanganan psikologis yang intensif. Mencatat temuan praktik telah menjadi kebiasaan di negara maju, seperti di Australia (Kleinschmidt, 2009), namun masih jarang ditemukan di Indonesia. Ilmuwan psikologi akan lebih mudah dalam mengembangkan keilmuan ketika para praktisi rajin dalam meng-ilmiah-kan temuan praktiknya di lapangan. Kesadaran untuk mengembangkan dua kebiasaan tersebut menjadi pekerjaan rumah bagi semua pihak yang terkait dalam hal pemulihan kondisi korban perdagangan manusia.

Jumlah partisipan yang terbatas merupakan keterbatasan utama dari penelitian ini. Latar belakang partisipan yang berbeda-beda tentu akan memperkaya potensi temuan penelitian, sehingga jumlah partisipan yang besar dapat memperkuat kualitas penelitian. Mengingat akses terhadap korban perdagangan manusia cukup terbatas dan sulit untuk diperoleh, penelitian selanjutnya perlu mempertimbangkan untuk mengalokasikan dana dan waktu yang lebih supaya dapat memperoleh jumlah partisipan yang memadai. Keterbatasan lain dari penelitian ini adalah analisis atau diskusi yang menggunakan sudut pandang psikologi yang idealnya juga diintegrasikan dengan sudut pandang lain yang relevan, misalnya sosiologi, hukum, ekonomi, dan kedokteran.

\section{SIMPULAN DAN SARAN}

\section{Simpulan}

Berdasarkan temuan penelitian, dapat dilihat bahwa motif ekonomi, keluarga, sosial, serta paksaan menjadi motif utama yang mendorong wanita untuk menjadi TKW ilegal dan menjadi korban perdagangan manusia. Penelitian ini juga mendapati bahwa rasa sedih dan tak berdaya, rasa malu, serta perilaku kerja yang maladaptif merupakan beberapa dampak psikologis jangka panjang yang dirasakan oleh korban perdagangan manusia di NTT.

\section{Saran Teoretis}

Untuk mengembangkan kajian terkait studi perdagangan manusia, diperlukan studi lebih intensif yang melibatkan beberapa disiplin ilmu terkait, seperti hukum, sosial, psikologi, dan ilmu lainnya. Hal ini memerlukan inisiasi dan koordinasi yang baik karena selama ini kajian mengenai perdagangan manusia lebih dominan dilakukan dari perspektif hukum dan sosial saja. 


\section{Saran Praktis}

Program preventif perlu menekankan kepada faktor risiko yang terkait dengan motif ini, yakni faktor kemiskinan, faktor peran dalam keluarga, faktor pandangan dalam komunitas, serta faktor paksaan dari penyalur tenaga kerja. Penguatan ekonomi keluarga, peningkatan kesadaran mengenai alternatif pekerjaan yang legal, serta penindakan tegas terhadap agen penyalur perlu dilakukan oleh pihak-pihak terkait, baik pemerintah, lembaga swadaya masyarakat, maupun pemimpin tingkat komunitas.

Mengeliminasi faktor risiko yang terkait dampak-dampak psikologis negatif, seperti stigma serta keterbatasan akses terhadap layanan kesehatan mental, perlu ditingkatkan oleh para pemangku kepentingan. Diperlukan kesadaran dari para praktisi psikologi untuk secara proaktif membantu proses intervensi terhadap korban perdagangan manusia. Intervensi yang menekankan pada rasa kebersamaan dan pemulihan konsep diri dapat membantu para korban perdagangan manusia ini. Direkomendasikan bagi orang tua dan keluarga korban agar berinisiatif untuk membangun lingkungan yang suportif terhadap korban. Lingkungan kerja yang baru juga perlu menekankan kebebasan memilih yang dimiliki korban. Penelitian ini juga perlu ditindaklanjuti dengan melakukan eksperimen terhadap metode intervensi apa yang bisa memberi dampak pemulihan psikologis secara efektif dan efisien kepada korban perdagangan manusia.

\section{UCAPAN TERIMA KASIH}

Terima kasih kami sampaikan kepada seluruh partisipan penelitian serta Dominggus Elcid Li yang sudah menginspirasi penulis dalam menulis artikel ini.

\section{REFERENSI}

Bentz, V. M., \& Shapiro, J. J. (1998). Mindful inquiry in social research. Thousand Oaks, CA: Sage.

Bergman, A. L. (2013). For their own good? Exploring legislative responses to the commercial sexual exploitation of children and the Illinois safe children act. Vanderbilt Law Review, 65(5), 1361-1400. 
Cho, S-Y., Dreher, A., \& Neumayer, E. (2013). Does legalized prostitution increase human trafficking? World Development, 41(1), 67-82. doi: 10.1016/j.worlddev.2012.05.023

Clarke, V., \& Braun, V. (2013). Teaching thematic analysis: Overcoming challenges and developing strategies for effective learning. The Psychologist, 26(2), 120-123.

Clayton, E. W., Krugman, R. D., \& Simon, P. (2013). Confronting commercial sexual exploitation and sex trafficking of minors in the United States. Washington, DC: The National Academies Press.

Cunningham, K. C.. \& Cromer, L. D. (2016). Attitudes About Human Trafficking: Individual Differences Related to Belief and Victim Blame. Journal of Interpersonal Violence, 31(2), 228-244. doi: 10.1177/0886260514555369

Denzin, K. N., \& Lincoln, Y. S. (1994). Handbook of qualitative research. Thousand Oaks, CA: Sage.

Fuadi, M. A. (2011). Dinamika psikologis kekerasan seksual: Sebuah studi fenomenologi. Psikoislamika, 8(2), 191-208.

Havlicek, J., Huston S., Boughton, S., \& Zhang, S. (2016). Human trafficking of children in Illinois: Prevalence and characteristics. Children and Youth Services Review, 69, 127-135. doi: 10.1016/j.childyouth.2016.08.010

Haynes, D. F. (2014). The celebritization of human trafficking. The Annals of American Academy of Political and Social Science, 653(1), 25-45. doi: 10.1177/0002716213515837

Hom, K. A., \& Woods, S. J. (2013). Trauma and its aftermath for commercially sexually exploited women as told by front-line service providers. Issues in Mental Health Nursing, 34(2), 7581. doi: $10.3109 / 01612840.2012 .723300$

Institute Resource Governance and Social Change. (2014). Human slavery in modern Indonesia. Ditemu kembali dari http://www.irgsc.org/slavery-in-indonesia.html

International Organization for Migration. (2012). IOM 2011 Case Data on Human Trafficking: Global Figures \& Trends. Ditemu kembali dari: https://ec.europa.eu/antitrafficking/sites/antitrafficking/files/iom_global_trafficking_data_on_assisted_cases_2012. pdf

Ismail, M. (2018). ASEAN: Epicentre of human trafficking. The ASEAN Post. Ditemu kembali dari https://theaseanpost.com/article/asean-epicentre-human-trafficking 
Jokowi: Stop perdagangan manusia. (2014). Tempo.co. Ditemu kembali dari http://www.tempo.co/read/news/2014/12/20/058629881/Jokowi-Stop-PerdaganganManusia

Kleinschmidt, L. (2009). Keeping mother alive: Psychotherapy with a teenager mother following human trafficking. Journal of Child Psychotherapy, 35(3), 262-275. doi: 10.1080/00754170903234416

Konrad, R. A., Trapp, A. C., Palmbach, T. M., Blom, J. S. (2017). Overcoming human trafficking via operations research and analytics: Opportunities for methods, models, and applications. European Journal of Operational Research, 259(2), 733-745. doi: 10.1016/j.ejor.2016.10.049

Macy, R. J., \& Johns, N. (2011). Aftercare services for international sex trafficking survivors: Informing U.S. service and program development in an emerging practice area. Trauma, Violence \& Abuse, 12(2), 87-98. doi: 10.1177/1524838010390709

Nguyen, P. T., Coverdale, J. H., \& Gordon, M. R. (2017). Identifying, treating, and advocating for human trafficking victims: A key role for psychiatric inpatient units. General Hospital Psychiatry, 46, 41-43. doi: 10.1016/j.genhosppsych.2017.02.006

Petrunov, G. (2014). Human Trafficking in Eastern Europe: The Case of Bulgaria. The Annals of American Academy, 653(1), 162-182. doi: 10.1177/0002716214521556

Rafferty, Y. (2007). Children for sale: Child trafficking in Southeast Asia. Child Abuse Review, 16(6), 401-422. doi: 10.1002/car.1009

Sintas. (2018). Dalam Kamus Besar Bahasa Indonesia. Ditemu kembali dari https://kbbi.web.id/sintas

Stotts, E. Jr., \& Ramey, L. (2009). Human trafficking: A call for counselor awareness and action. Journal of Humanistic Counseling, Education, and Development, 48(1), 36-47. doi: 10.1002/j.2161-1939.2009.tb00066.x

Undang-Undang Republik Indonesia. (2007). Undang-Undang Republik Indonesia nomor 21 tahun 2007 tentang pemberantasan tindak pidana perdagangan orang. Ditemu kembali dari http://www.kemenpppa.go.id/jdih/peraturan/UU-21-2007.pdf

United Nations Office on Drugs and Crime. (2009). Anti-human trafficking manual for criminal justice practitioner. Ditemu kembali dari http://www.unodc.org/documents/humantrafficking/TIP_module3_Ebook.pdf 
United Nations Office on Drugs and Crime. (2019). Human trafficking. Ditemu kembali dari https://www.unodc.org/unodc/en/human-trafficking/what-is-human-trafficking.html

Welman, J. C., \& Kruger, S. J. (1999). Research methodology for the business and administrative sciences. Johannesburg, SA: International Thompson.

Wooditch, A. (2012). Human trafficking law and social structures. International Journal of Offender Therapy and Comparative Criminology, 56(5), 673-690. doi: 10.1177/0306624X11415964

World Health Organization. (2012). Understanding and addressing violence against women. (2012). Ditemu kembali dari http://apps.who.int/iris/bitstream/10665/77394/1/WHO_RHR_12.42_eng.pdf

Zimmerman, C., \& Hossain, M. C. W. (2011). Human trafficking and health: a conceptual model to inform policy, intervention and research. Social Science \& Medicine, 73(2), 327-335. doi: 10.1016/j.socscimed.2011.05.028

Zimmerman, C., \& Watts, C. (2004). Risk and responsibilities: guidelines for interviewing trafficked women. The Lancet, 363(9408), 565. doi: 10.1016/S0140-6736(04)15547-5 